\title{
Upaya Pemerintah Indonesia dalam Meningkatkan Pariwisata Mandalika Melalui Kerangka Branding 'Wonderful Indonesia'
}

\author{
Muhammad Arief Satrio \\ Universitas Airlangga
}

\begin{abstract}
This paper describes the Indonesian government's efforts in developing Mandalika through the framework of the nation brand 'Wonderful Indonesia'. This effort is a form of government commitment to make Indonesia the world's maritime axis. If derived from the tourism sector, it can be interpreted as making the maritime tourism industry a top priority. This is manifested by the launch of 10 Priority Destinations where 8 of the 10 destinations are the maritime tourism industry, one of which is Mandalika which is located in West Nusa Tenggara. The government has made efforts to develop the $3 A$ sector, namely accessibility, amenities and attractions. The development is managed by PT ITDC, a state-owned company engaged in the tourism sector and collaborates with foreign investors. In addition to the development of $3 A$, efforts were made to promote abroad as a form of public diplomacy and a form of efforts to promote the Mandalika Area in the corridor of the 'Wonderful Indonesia' branding.
\end{abstract}

Keywords: Mandalika; accessibility; amenities; attractions; tourism promotion

\begin{abstract}
Abstrak
Tulisan ini mendeskripsikan upaya pemerintah Indonesia dalam mengembangkan pariwisata Mandalika melalui kerangka nation brand 'Wonderful Indonesia'. Upaya ini sebagai bentuk komitmen pemerintah untuk menjadikan Indonesia sebagai poros maritim dunia. Jika diturunkan dalam sektor pariwisata, dapat diartikan sebagai menjadikan industri pariwisata maritim sebagai prioritas utama. Hal ini diwujudkan dengan peluncuran 10 Destinasi Prioritas dimana 8 dari 10 destinasi tersebut adalah industri pariwisata maritim, salah satunya Mandalika yang terletak di Nusa Tenggara Barat. Upaya yang dilakukan pemerintah dilakukan adalah dengan mengembangkan sektor $3 A$, yatu aksesibilitas, amenitas dan atraksi. Pengembangan itu dikelola oleh PT ITDC, BUMN yang bergerak di sektor pariwisata serta menggandeng investor asing. Di samping pengembangan $3 A$, upaya dilakukan dengan promosi ke luar negeri sebagai bentuk diplomasi publik dan bentuk upaya mempromosikan Kawasan Mandalika dalam koridor branding 'Wonderful Indonesia'.
\end{abstract}

Kata-kata kunci: Mandalika; aksesibilitas; amenitas; atraksi; promosi pariwisata 


\section{Pendahuluan}

Seiring dengan perkembangan zaman, diplomasi juga mengalami perubahan yang sangat dinamis. Diplomasi yang dilakukan juga tidak hanya melibatkan aktor negara, tetapi saat ini publik juga memiliki peran. Adanya teknologi yang semakin canggih membuat tren yang banyak dilakukan negara saat ini adalah dengan diplomasi publik. Dengan melakukan diplomasi publik, negara bisa mempromosikan apa potensi yang dimiliki dan meningkatkan citra baik kepada dunia. Di Indonesia, diplomasi publik dijadikan ajang untuk memperkenalkan potensi khususnya budaya dan pariwisata kepada dunia internasional. Adapun pengembangan sektor pariwisata Indonesia tertuang dalam dalam Instruksi Presiden Republik Indonesia Nomor 9 Tahun 1969, khususnya Bab II Pasal3, yang menyebutkan "Usaha-usaha pengembangan pariwisata di Indonesia bersifat suatu pengembangan "industri pariwisata" dan merupakan bagian dari usaha pengembangan dan pembangunan serta kesejahtraan masyarakat dan Negara". Dari penjelasan tersebut, cukup jelas bahwa pengembangan pariwisata diharapkan dapat menjadi salah satu pemasukan devisa negara yang tertinggi.

Dalam mendukung upaya diplomasi publik guna meningkatkan citra Indonesia ke mata dunia, Pemerintah juga meluncurkan nation branding yang menjadi identitas negara dalam melakukan promosi pariwisatanya. Pemerintah meluncurkan brand 'Wonderful Indonesia' pada tahun 2011 dengan menggencarkan potensi pariwisata yang sangat beragam untuk diperkenalkan kepada dunia. Letak geografis yang strategis di antara dua benua yaitu benua Asia dan Australia dan dua samudera yaitu samudera Pasifik dan Hindia juga menjadi pendukung kuat potensi pariwisata Indonesia. Letak Indonesia yang strategis tersebutjuga menjadikan Indonesia dapat menjadi negara poros maritim dunia. Presiden Joko Widodo pernah berpidato di Nay Piy Taw Myanmar dalam agenda Konferensi Tingkat Tinggi East Asia Summit (EAS) ke-9 bahwa Indonesia akan menjadi poros maritim dunia. Jika diturunkan dalam koridor pariwisata, dapat diartikan sebagai peningkatan pariwisata melalui pariwisata maritim. Pariwisata maritim Indonesia memang memiliki daya tarik yang beragam

Dalam perkembangannya sampai tahun 2019, wisatawan mancanegara yag masuk ke negeri kita ini terus bertambah setiap tahunnya. Jumlah kunjungan tertinggi ada pada tahun 2019 dengan jumlah wisatawan yang masuk ke Indonesia sebesar 16.106.954 wisatawan (Badan Pusat Statistik, 2020). Namun dibanding dengan jumlah kunjungan dengan wisatawan mancanegara di negara-negara Asia Tenggara, Indonesia menempati urutan keempat. Urutan pertama yaitu Thailand sebesar 39,8 juta wisatawan pada tahun 2019, disusul Malaysia dan Singapura dengan 
jumlah wisatawan mancanegara sebesar 26,1 juta dan 19,1 juta wisatawan (Statista Research Development, 2020).

Dengan meningkatnya turis asing berbagai negara datang mengunjunginegarakitainidan perbandingankunjunganturismancanegara ke beberapa negara Asia Tenggara, pemerintah terus berupaya dalam meningkatkan jumlah pariwisata yang datang ke Indonesia agar dapat sejajar dengan negara lain. Beberapa cara-cara yang diupayakan pemerintah yaitu melalui promosi nation brand yaitu 'Wonderful Indonesia'. Nation brand ini pertama kali diperkenalkan oleh Kementrian Pariwisata pada tahun 2011 menggantikan brand lamanya yaitu 'Visit Indonesia".

Kemudian pada tahun 2016 lalu, pemerintah melalui Kementerian Pariwisata merilis '10 Bali Baru' yang mana merupakan destinasi pariwisata prioritas di Indonesia yang diharapkan bisa mendatangkan wisatawan sebanding dengan wisatawan yang datang ke Pulau Bali. Hal ini tidak bisa dipungkiri bahwa 40\% wisatawan mancanegara yang masuk ke Indonesia melalui gerbang wisata Pulau Dewata. Namun, bukan berarti dengan adanya 10 destinasi prioritas ini, semuanya dimiripkan dengan pariwisata yang ada di Pulau Bali. 10 Pariwisata tersebut tetap memiliki karakteristiknya masing-masing.

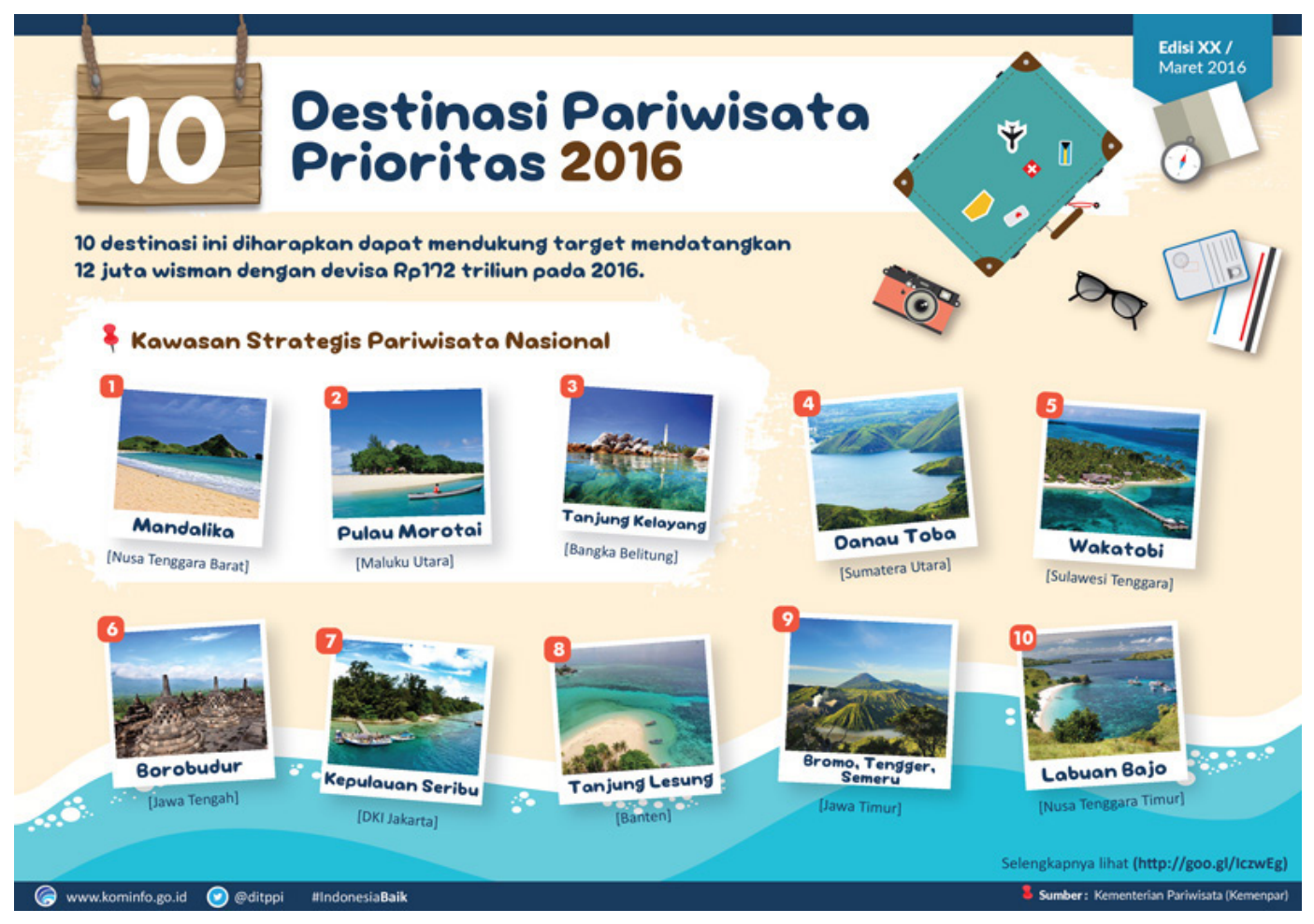

Gambar 1. Lokasi 10 Destinasi Prioritas

(Kominfo, 2016) 
Salah satu dari sepuluh destinasi yang sedang dikembangkan oleh pemerintah adalah Mandalika Lombok. Mandalika Lombok juga menjadi objek dari penelitian penulis karena destinasi wisata tersebut menjadi salah satu yang memenuhi tiga dari lima sektor pembangunan nasional 2017. Lima sektor pembangunan prioritas tersebut yaitu pangan, energi, maritim, pariwisata, serta kawasan industri dan Kawasan Ekonomi Khusus (KEK). Adapun Mandalika memenuhi tiga sektor tersebut yaitu maritim, pariwisata dan Kawasan Ekonomi Khusus (KEK).

Mandalika merupakan kawasan wisata yang terletak di Lombok Tengah, Nusa Tenggara Barat. Kawasan wisata Mandalika dengan ukuran lahannya yang mencapai $1.035,67 \mathrm{hm}^{2}$ dimana lahan tersebut pengelolaanya berada dibawah PT Indonesia Tourism Development Corporate (ITDC) dimana mempunyai keunikan yaitu pantai dengan Panjang 14,6km. 'Wonderful Indonesia' memiliki peran penting disini, khususnya mempromosikan destinasi pariwisata tersebut. Melalui brand tersebut, nantinya akan dipromosikan potensi pariwisata yang ada pada kawasan wisata Mandalika Lombok, Nusa Tenggara Barat. Namun, promosi potensi pariwisata yang ada di kawasan tersebut tentunya masih perlu dibarengi dengan upayaupaya dalam meningkatkan kondisi pariwisata yang terdapat di Mandalika. Ada beberapa studi terdahulu yang relevan dengan penelitian ini. Dijelaskan bahwa ada empat media yang menjadi strategi pemerintah Indonesia dalam melakukan promosi pariwisatanya dalam kerangka branding 'Wonderful Indonesia', yaitu media online, media elektronik, media cetak serta media ruang. Media tersebut menyasar ke pasar domestik maupun internasional (Yuristiadhi \& Sari, 2017). Di samping itu, strategi yang diplakukan juga perlu adanya dukungan bukan hanya dari sektor pemerintah tapi dari sektor swasta (Sugi \& Putri, 2019). Selain itu, strategi yang dapat dilakukan dalam mendukung industri pariwisata adalah dengan meningkatkan infrastruktur, seperti sarana transportasi (Wiratama, 2017).

Penelitian lain terkait promosi pariwisata Mandalika, Nurlelawati berpendapat bahwa sektor pariwisata menjadi sektor yang yang memiliki prospek besar dimasa mendatang. Dalam upaya meningkatkan jumlah kunjungan wisatawan ke Mandalika, pemerintah melakukan upaya promosinya dengan mengikuti pameran serta international tourism activities dengan memperkenalkan potensi pariwisata yanga ada. Promosi pariwisata di mancanegara dilakukan dengan mengikuti beberapa tourism exhibition seperti di Belanda, Malaysia, serta Singapura (Nurlelawati, 2019). Dalam tulisan lainnya, mengenai diplomasi pariwisata halal Nusa Tenggara Barat, dijelaskan bahwa ada dua aspek yang ditekankan yaitu adanya payung hukum dalam penyelenggaraan wisata halal serta keterlibatan masyarakat dalam mempromosikan Nusa Tenggara Barat sebagai wisata ramah muslim (Subarkah, 2018). 
Pada penelitian ini, penulis akan lebih memfokuskan penelitian bukan hanya melalui upaya promosi pariwisata Mandalika ke mancanegara saja. Tetapi juga menyoroti upaya pengembangan kawasan wisata Mandalika yang dipersiapkan sebagai kawasan wisata bertaraf internasional. Pengembangan tersebut dibagi menjadi tiga aspek, yaitu aksesibilitas, amenitas dan atraksi. Penulis juga menjabarkan apa dampak yang terjadi dengan pembangunan kawasan Mandalika sebagai salah satu dari 10 destinasi prioritas.

\section{Kerangka Konseptual: Diplomasi Publik dan Nation Brand}

Upaya Indonesia dalam meningkatkan pariwisata maritim di Mandalika merupakan salah satu bentuk soft diplomacy yang mana merupakan bentuk diplomasisecara damai dalam bidang kebudayaan, bahasa, persahabatan, ekonomi dan lain-lain. Dengan dinamika perkembangan zaman dan berkembangnya teknologi, soft diplomacy banyak digunakan negara untuk memperkenalkan potensi yang dimilikinya untuk meciptakan citra baik kepada masyarakat dunia. Diplomasi tersebut dinamakan diplomasi publik. Cull (2009) menyatakan bahwa diplomasi publik merupakan upaya yang dilakukan aktor-aktor internasional dalam melakukan aktivitas internasionalnya dengan melibatkan publik internasional. Adapun diplomasi publik dalam prakteknya memiliki enam perspektif fungsional yang tujuannya meliputi: advokasi atau mempengaruhi opini publik mancanegara; komunikasi atau memberikan informasi kepada masyarakat atau bangsa lain; membangun atau melanjutkan hubungan yang memiliki manfaat dengan masyarakat di negara lain; mempromosikan atau 'menjual' aspek tertentu dari sebuah negara kepada publik internasional; melibatkan diri pada politik internasional; dan ropaganda dalam mendukung upaya militer (Fitzpackrick, et al., 2013). Dari penjelasan tersebut, jelas bahwa negara bukan satu-satunya aktor tunggal dalam hubungan internasional, melainkan terdapat aktor lainnya seperti swasta dan masyarakat. Isu yang diangkat juga bukan hanya isu high politics tetapi juga low politics.

Salah satu bentuk diplomasi publik yang banyak dilakukan negara saat ini adalah melalui nation branding. Nation branding merupakan proses dimana citra suatu negara diciptakan, dipantau, dievaluasi dan dikelola secara proaktif untuk memperbaiki atau meningkatkan reputasi negara dengan target masyarkat internasional (Fan, 2010). Defnisi lain nation branding menurut Simon Anholt dijelaskan sebagai identitas kompetitif, yaitu representasi strategis sebuah negara untuk meningkatkan dan/atau mempertahankan daya saing politik dan ekonominya di era global (Anholt, 2007). Berdasarkan pengertian tersebut, diperoleh makna mengenai sebuah negara dalam membuat nantion branding harus memperhatikan citra negara dan reputasinya. Citra negara ini tentunya harus sesuai dengan identitas 
bangsa. Reputasi terhadap citra suatu bangsa ini dipengaruhi oleh stereotip, pengaruh media dan pengalaman pribadi. Jadi reputasi terhadap citra negara dipengaruhi oleh orang lain, dalam hal ini yang dimaksudkan masyarakat dunia. Sedangkan persepsi nation branding menurut Simon Anholt adalah bahwa dunia ini merupakan pasar yang terintegrasi sehingga setiap negara memiliki daya saing satu sama lain dan masyarakat internasional yang menjadi konsumennya.

Nation branding dan diplomasi publik memiliki keterkaitan yang sangat erat. Diplomasi publik dapat berlangsung tanpa sebuah nation branding. Namun, nation branding tidak dapat berjalan tanpa adanya praktek dari diplomasi publik. Hal ini dapat dilihat pada alat evaluasi nation branding yang disebut dengan National Brand Pentagon (Amine \& Chao, 2005). National Brand Pentagon memiliki lima unsur dimana nation branding dapat dikatakan ideal, antara lain: mempromosikan pariwisata, mempresentasikan budaya, mendorong ekspor, menarik investasi dan didukung oleh kebijakan luar negeri seperti diplomasi publik. Jika lima unsur tersebut terpenuhi dalam nation branding, maka akan terbentuk segi lima sempurna sebagai berikut:

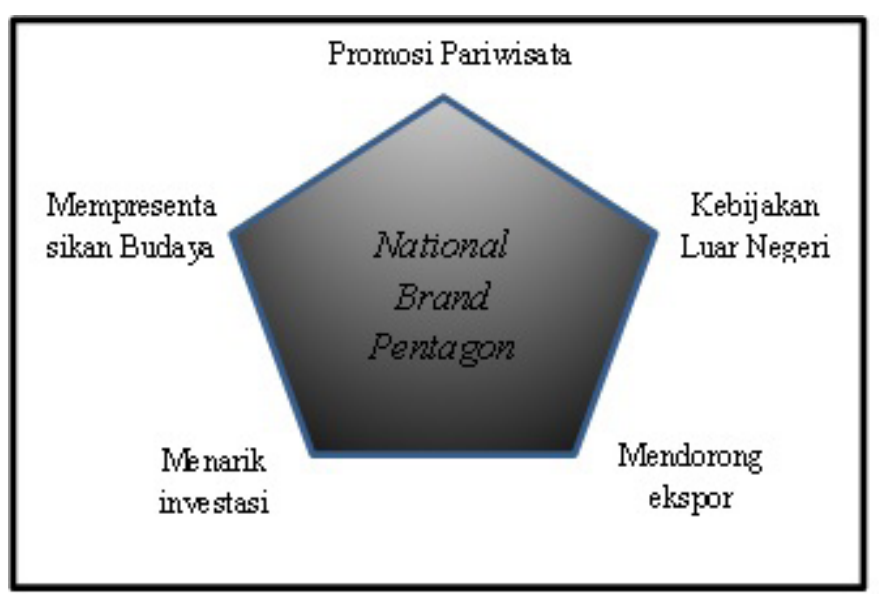

Nation brand yang dimiliki Indonesia saat ini dalam mempromosikan pariwisatanya adalah 'Wonderful Indonesia'. Wonderful yang dalam Bahasa Indonesia berarti 'pesona' adalah sebuah janji dimana Indonesia sangat berlimpah, yang akan membuat semua orang takjub dengan semua aspek yang ada di Indonesia, baik SDM maupun SDA, yang mana dapat mengusik kalbu dan memberikan janji dan pengalaman yang baru serta menyenangkan. 


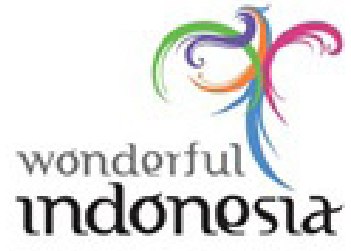

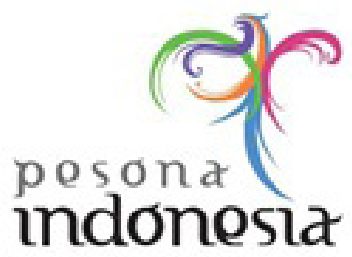

Gambar 3. Logo 'Wonderful Indonesia' dan 'Pesona Indonesia'

(Kementerian Pariwisata dan Ekonomi Kreatif, 2019)

Konsep Logo 'Wonderful Indonesia' atau 'Pesona Indonesia' melambangkan burung. Di Indonesia sendiri ada banyak jenis dan serta jumlah burung, dimana salah satu burung gagah pun digunakan sebagai lambing negara kita. Sayap burung di logo tersebut dibuat merentang, memiliki arti terbuka dimana adanya keinginan untuk mengepakkan sayapnya jauh ke seluruh dunia dan dikenali oleh banyak orang. Tulisan 'Indonesia' yang hitam dan ukurannya lebih besar ini mendorong Indonesia untuk menjadi negara terkuat dan terdepan dalam bersaing di pariwisata global. Filosofi bentuk yang luwes, serba lengkung, tanpa sudut persegi ataupun garis lurus, bermakna untuk menyeimbangkan dan menjaga agar tetap selaras di antara alam dengan manusia dan antar sesama bumi.

Brand 'Wonderful Indonesia' ini pertama kali diluncurkan tahun 2011 oleh Kementerian Pariwisata menggantikan brand lamanya 'Visit Indonesia'. Dalam meluncurkan brand ini, fokus Indonesia dalam melakukan promosi ke luar negeri fokus menargetkan ke 16 negara dan kawasan. Pasar pemasaran tersebut meliputi pasar utama, diantaranya Singapura, Malaysia dan Australia; Pasar sekunder/primer, yaitu Tiongkok, Jepang, Korea Selatan, Filipina, Taiwan, Amerika Serikat, Inggris dan Perancis; serta pasar potensial, yaitu India, Belanda, Timur Tengah, Jerman dan Rusia (Indarsih, 2016).

\section{Profil Kawasan Mandalika}

Kawasan wisata Mandalika merupakan salah satu kawasan destinasi prioritas yang terletak di Lombok, Nusa Tenggara Barat. Kawasan wisata Mandalika dengan ukuran lahan 1.035,67 $\mathrm{hm}^{2}$. Pada awalnya, kawasan Mandalika merupakan proyek kawasan wisata yang sudah 29 tahun dikerjakan namun tidak selesai. Lambatnya proyek pembangunan kawasan wisata tersebut dikarenakan tidak adanya payung hukum berupa Instruksi Presiden (Inpres) yang membuat jajaran pemerintahan daerah tidak berani untuk mengambil tindakan khususnya pembebasan lahan di kawasan Mandalika. Kemudian pada tahun 2016, Presiden Joko Widodo menerbitkan 
Instruksi Presiden, didalamnya ada aturan mengenai pembebasan lahan. Dengan masuknya Mandalika ke dalam Proyek Strategis Nasional tersebut menjadi harapan bagi negara dan masyarakat sekitar agar ekonomi didaerah tersebut lebih maju.

Kawasan wisata Mandalika oleh Pemerintah khususnya Kementerian Pariwisata menjadi salah satu prioritas karena beberapa alasan, antara lain: pertama, kawasan wisata Mandalika dengan ukuran $1.034 \mathrm{hm}^{2}$ ini di kelola oleh PT. Indonesia Tourism Development Corporate (ITDC), salah satu Badan Usaha Milik Negara yang telah berhasil dalam pembangunan Nusa Dua di Bali. Kedua, posisinya dapat dikatakan mudah dijangkau di Pulau Lombok, jaraknya hanya 30 menit dari Bandara Internasional Lombok dan terbentang mulai dari Pantai Kuta, Pantai Seger, hingga Pantai Tanjung Aan. Ketiga, berlokasi di Kawasan Ekonomi Khusus Mandalika, pantai ini menjadi salah satu dari 10 tempat wisata yang menjadi prioritas nasional karena mempunyai keunikan yaitu adanya pantai dengan Panjang 14,6 kilometer yang membentang hingga ujung timur Pantai Tanjung Aan dengan keunikan pasir putihnya yang menyerupai biji merica. Keempat, dalam memasuki Kawasan Ekonomi Khusus Mandalika pertama kali akan dilewati yaitu Pantai Kuta dengan keunikan pasir putihnya dan juga kejernihan air lautnya, ditambah dengan pemandangan bukit. Kelima, terdapat Desa Adat Sade dan Desa Adat Ende khas masyarakat Sasak, suku asli Pulau Lombok lokasinya berdekatan dengan Mandalika.

Program pengembangan pariwisata merupakan suatu program pembangunan yang memiliki potensi untuk menciptakan kesempatan kerja yang lebih besar, dan dapat dijadikan ujung tombak untuk meningkatkan devisa negara. Pertimbangan ekonomis dalam pengembangan pariwisata seharusnya tidak meninggalkan pertimbangan dalam kehidupan sosial dan budaya yang negatif. Oleh karena itu antara pertimbangan ekonomi dan moral harus seimbang dan mampu dijadikaan acuan dalam mempertimbangkan putusan-putusan yang sesuai dalam pengembangan pariwisata maritim, khususnya di kawasan wisata Mandalika.

Indonesian Tourism Development Corporation (ITDC) sedang dalam tahap penataan wilayah tersebut selain untuk dapat menjadi pendorong dalam perekonomian masyarakat namun juga untuk memberikan multiplier effect yang besar bagi rakyat Nusa Tenggara Barat. Sehingga, dengan diresmikannya kawasan wisata Mandalika serta dengan mulai berfungsinya sejumlah proyek tersebut di masa yang akan datang, rasa percaya diri terhadap potensi pariwisata maritim di Mandalika yang memiliki kemampuan untuk menjadi tempat wisata yang memiliki standar internasional di negara kita atau di bali. Hal ini, akan menjadikan kebanggaan bagi bangsa Indonesia yang mampu menjadikan Mandalika, yang dulunya belum dikenal oleh masyarakat luas khususnya di luar Nusa 
Tenggara Barat saat ini telah menjadi terkenal dan namanya tidak asing lagi khususnya bagi para wisatawan.

Sebagai bentuk promosi dari brand 'Wonderful Indonesia', pemerintah khususnya Kementerian Pariwisata juga melakukan upaya untuk mengembangkan pariwisata di Indonesia sehingga memiliki daya tarik oleh wisatawan baik domestik maupun mancanegara melalui pengembangan Kawasan Ekonomi Khusus (KEK) di sektor pariwisata. Sektor ini ditujukan untuk berbagai aktivitas kepariwisataan dan menjadi pendukung dari disekenggarakannya berbagai hiburan atau kegiatan lainnya. Dengan keanekaragaman alam sekitar serta berbagai jenis atraksi atau kegiatan wisata alam, KEK menjadi salah satu hal yang dapat dilakukan Pemerintah untuk mengembangkan pariwisatanya, misalnya dengan menarik investasi asing untuk menanamkan modal untuk membangun berbagai fasilitas maupun infrastruktur di kawasan wisata tersebut. Dengan penetapan beberapa kawasan wisata sebagai KEK diharapkan dapat menjadi objek wisata terintegrasi (integrated area tourism) antara wisata alam, wisata budaya hingga wisata MICE (MICE dan events tourism).

KEK Mandalika yang terletak di Lombok, Nusa Tenggara Barat. Kawasan dengan luas 1.035,67 hektar tersebut telah difokuskan untuk aktivitas yang diprioritaskan di sektor pariwisata. Fokus pada sektor pariwisata ini tentu saja membutuhkan dukungan yang besar dari pemerintah dan berbagai pihak sehingga nantinya dapat menjadi destinasi pariwisata bertaraf internasional. Penetapan Mandalika menjadi KEK ini berdasarkan PP Nomor 52 Tahun 2014 dan diharapkan dapat meningkatkan pendapatan devisa negara pada umumnya dan kesejahteraan masyarakat Nusa Tenggara Barat melalui dibukanya peluang kesempatan kerja pada khususnya. KEK Mandalika diresmikan oleh Presiden Jokowi. Rencananya, pembangunan KEK Mandalika akan dilaksanakan dalam kurun waktu 10 tahun dengan nilai investasi sebesar Rp. 4,54 triliun dari ITDC serta Rp. 250 milyar yang berasal dari komitmen pemerintah dalam bentuk penyertaan modal (Hartono \& Faozaeni, 2018). Selain investasi dalam negeri, pembangunan KEK Mandalika juga menggandeng beberapa investor asing. Rencananya, investasi pengembangan KEK Mandalika terdiri dari, membangun hotel-hotel berbintang lima yaitu Pullman, Club Med, Royal Tulip, X2 Hotel, dan Hotel Paramount yang nilai investasinya bernilai Rp. 4,2 triliun, komplek muslim senilai Rp. 2 triliun, dan water treatment (mengelola air yang layak konsumsi) yaitu sea water osmosis yang memiliki kapasitas $3.000 \mathrm{~m}^{3}$ /hari dengan nilai investasi Rp. 300 miliar (CNN Indonesia, 2017). Akan tetapi, di antara berbagai investasi tersebut, rencana yang memiliki nilai tinggi datang dari perencanaan dalam membangun circuit untuk MotoGP 2020 yang dikelola oleh Vinci Contruction dengan nilai Rp. 14 Triliun (Detik, 2019). 
Dalam suatu pengembangan kawasan wisata, akan terjadi masalahmasalah yang mungkin akan dihadapi pemerintah dan masyarakat. Permasalahan tersebut muncul dari multi sektor, seperti ekonomi, sosial budaya dan lingkungan. Namun demikian, dampak positif yang akan muncul antara lain: pertama, membuka lapangan kerja. Dari sektor ekonomi, dengan adanya Kawasan Ekonomi Khusus Mandalika tentu saja akan membutuhkan Sumber Daya Manusia (SDM) yang jumlahnya tidak sedikit sehingga dapat membuka membuka kesempatan kerja. Di samping itu, akan memberi kesempatan untuk siapapun yang akan melakukan usaha jasa yang dapat menyiadakan sarana bagi wisatawan serta menambah pemasukan bagi pihak yang membuka usaha tersebut. Dari sisi ketenagakerjaan, proyeksi dengan adanya pembangunan KEK Mandalika, akan menyerap lebih dari 5.000 tenaga kerja dengan masuknya berbagai investor asing dalam melakukan pengembangannya (Hartono \& Faozaeni, 2018). Tenaga kerja yang diserap, sebagian besar disalurkan oleh ITDC. Dengan adanya proyek KEK Mandalika ini diharapkan Pemerintah Daerah melalui lembaga yang berwenang, dalam hal ini ITDC, dapat mengambil andil dalam penempatan tenaga kerja. Seperti kita ketahui bahwa Nusa Tenggara Barat merupakan salah satu penyalur Tenaga Kerja Indonesia (TKI) terbanyak. Oleh karena itu, dengan adanya KEK Mandalika diharapkan dapat menjadi salah satu pusat destinasi di Lombok yang mampu memberdayakan tenaga kerja lokal, khusunya tenaga kerja di Nusa Tenggara Barat. Sehingga masyarakat sekitar dapat menikmati dan menghargai kebijakan-kebijakan yang diterapkan oleh pemerintah. Keberadaan kawasan pariwisata di suatu daerah akan membuka kesempatan kerja bagi masyarakat sekitar dan menyebabkan adanya peningkatan peningkatan kualitas SDM yang terlatih serta meningkatkan taraf hidup bagi mereka.

Kedua, meningkatkan pendapatan daerah dan negara. Dengan adanya Kawasan Ekonomi Khusus (KEK) Mandalika yang semakin dikenal, maka kunjungan wisatawan akan semakin meningkat dan berdampak pada naiknya pendapatan daerah pada khususnya, dan negara pada umumnya. Pembangunan KEK Mandalika ini diproyeksikan apabila telah selesai pada tahun 2025, akan mendapat kunjungan wisatawan sebanyak dua juta wisatawan per tahun serta dapat memberikan kontribusi ke dalam devisa Negara senilai Rp7,5T dan juga penyumbang PDB pada sektor pariwisata sebanyak Rp. 16,69 triliun (Bappeda NTB, n.d.).

Ketiga, transfer teknologi. Adanya kawasan pariwisata seperti di Mandalika akan membentuk masyarakat yang pada awalnya belum mengenal IPTEK menjadi masyarakat modern yang menguasai IPTEK. Penguasaan IPTEK akan menjadikan masyarakat lebih mudah untuk mengakses segala masalah yang nantinya dapat diterapkan di wilayah kawasan paiwisata tersebut. Contohnya, tersedianya sarana komunikasi yang memadai, misalnya akses internet yang mudah (akses wifi). Komunikasi sudah mudah dilakukan karena tersedianya peralatan yang 
memadai, seperti handphone dan internet. Perlatan ini akan lebih mudah digunakan apabila akses internet juga mudah diperoleh. Oleh karena itu, kawasan wisata perlu menyediakan layanan akses internet.

Keempat, pengenalan budaya Indonesia khususnya daerah Lombok ke dunia luar. Daerah Lombok memiliki budaya yang dapat dijadikan keunggulan yang menjadi daya tarik bagi turis asing untuk mengunjungi kawasan pariwisata yang dibangun diwilayah tersebut. Pengenalan budaya dapat dilakukan antara lain dengan pertunjukkan kesenian khas Lombok yang dipentaskan di depan para wisatawan khususnya wisatawan mancanegara.

Kelima, tata kota semakin teratur. Keberadaan kawasan wisata khsusunya di Lombok akan menjadikan pemerintah khususnya menangani sektor pariwisata akan memikirkan masalah tata kota, sehingga para wisatawan akan lebih mudah untuk menjangkau daerah yang akan dituju. Disamping dampak positif, ternyata masih ada aspek-aspek yang perlu ditingkatkan dan diperbaiki dari adanya pembangunan Kawasan Ekonomi Khusus Mandalika, yaitu antara lain: pertama, kesenjangan sosial. Dalam sektor ekonomi dan sosial, masalah kesenjangan sosial sering dikaitkan dengan kehidupan suatu masyarakat. Kehidupan masyarakat di daerah Lombok, terdapat beberapa pada tingkat SDM, mulai dari tingkat rendah hingga tinggi. Kesenjangan antara golongan kaya dan miskin di Nusa Tenggara Barat dapat diukur dengan dengan Indeks Gini. Pada bulan Maret 2018, Indeks Gini di wilayah Nusa Tenggara Barat berada pada posisi 0,372 poin. Namun, indeks tersebut mengalami kenaikan pada bulan September 2018 hingga mencapai 0,379 poin (Badan Pusat Statistik Nusa Tenggara Barat, 2019).

Kedua, tingkat pengangguran. TPT (Tingkat Pengangguran Terbuka) di NTB pada bulan Agustus 2019 berada di tingkat 3,42 persen, tingkat pengangguran tersebut dapat dikatakan lebih rendah 0,3 persen apabila dibandingkan dengan TPT bulan Agustus 2018 yang berada pada angka 3,72 persen. Pada bulan Agustus 2019, TPT didominasi oleh masyarakat yang berpendidikan Sekolah Menengah Kejuruan (SMK), yaitu 9,63 persen. TPT tertinggi berikutnya adalah masyarakat dengan pendidikan Diploma I/II/III sebanyak 6,66 persen kemudian SMA sebanyak 6,07 persen (Inside Lombok, 2019). Masih tingginya tingkat kesenjangan sosial di Mandalika menjadikan catatan bagi pemerintah khususnya pemerintah daerah Nusa Tenggara Barat untuk dapat mendorong peningkatan taraf sejahtera yang ada di masyarakat sekitar.

Ketiga, kerusakan lingkungan dan ekosistem. Pembangunan kawasan wisata Mandalika juga perlu memperhatikan dampaknya terhadap lingkungan. Dampak-dampak yang perlu diperhatikan antara lain pengolahan limbah, pengolahan air bersih, drainase sebagai upaya preventif dalam menanggulangi banjir, illegal logging serta menanggulangi permasalahan 
sampah yang akan terjadi. Dalam menanggulangi hal ini, perlu adanya penegakan hukum yang lebih progressif untuk mencegah kerusakan lingkungan yang lebih masif lagi.

\section{Upaya Pemerintah Indonesia dalam Mengembangkan Kawasan Wisata Mandalika}

Kawasan wisata Mandalika merupakan salah satu urutan teratas kawasan wisatawan di Indonesia yang memiliki potensi untuk dijadikan kawasan wisata bertaraf Internasional. Selain upaya pemerintah untuk menjadikan daerah tersebut menjadi KEK, pemerintah juga berupaya meningkatkan Aksesibilitas, Amenitas dan Atraksi atau sering disingkat dengan '3A' untuk mendorong promosi brand 'Wonderful Indonesia' baik di sekitar maupun di dalam kawasan Mandalika. Aksesibilitas merupakan tingkat kemudahan dalam menjangkau kawasan tersebut. Aksesibilitas juga diartikan sebagai jaringan sarana dan prasana yang dimana menghubungkan satu wilayah dengan wilayah lain yang dijadikan pintu utama untuk turis dalam berkunjung ke suatu kawasan pariwisata. Sedangkan amenitas merupakan sarana yang mendukung dimana dapat menjadi aspek pemenuhan apa yang turis butuhkan dan inginkan. Amenitas berkaitan dengan ketersediaan sarana akomodasi yang digunakan untuk menginap atau tinggal sementara, serta adanya restoran atau warung yang menyediakan makanan dan minuman bagi para pengunjung. Dengan adanya unsur amenitas yang mendukung, maka akan berpengaruh terhadap kelangsungan kegiatan wisata di suatu daerah. Di samping itu, atraksi yang berkaitan dengan produk utama suatu destinasi dapat dikaitkan dengan apa yang dapat dilihat dan dilakukan oleh wisatawan saat berada di destinasi tersebut. Atraksi juga dapat didefinisikan sebagai daya tarik apa yang ada di kawasan wisata tersebut agar dapat menarik wisatawan.

Dari sektor aksesibilitas, lokasi KEK Mandalika terdapat dua pintu gerbang masuk utama yaitu Bandara Internasional Lombok sebagai jalur udara dan beberapa jalur laut melalui beberapa pelabuhan. Beberapa pelabuhan tersebut adalah Pelabuhan Lembar yang merupakan pintu masuk wisatawan dari Pulau Bali, Pelabuhan Kayangan yang merupakan pintu masuk dari Pulau Sumbawa, serta Pelabuhan Pemenang yang merupakan pintu masuk wisatawan mancanegara. Dari jalur udara, lokasi kawasan Mandalika tersebut memiliki akses yang mudah dijangkau karena kawasan tersebut berjarak tempuh 30 menit dari Bandara Internasional Lombok, Praya. Rute penerbangan internasional yang telah dibuka sekarang ini adalah penerbangan dari Malaysia, Singapura dan Australia. Namun, pemerintah telah berencana mengupayakan untuk membuka rute penerbangan internasional langsung dari Brunei Darussalam, Tiongkok, 
hingga negara-negara di kawasan Timur Tengah untuk masa depan. Beberapa maskapai internasional tersebut sudah melakukan observasi terkait dengan pembukaan rute internasional dari dan ke Lombok.

Pengembangan Bandara Internasional Lombok juga dilakukan oleh BUMN Angkasa Pura dengan menambah panjang landas pacu pesawat yang semula 2.750 meter menjadi 3.330 meter sehingga pesawat berbadan besar dapat mendarat langsung. Pengembangan juga dilakukan dengam memperluas terminal menjadi 40 ribu meter persegi dimana proyeksinya dapat menampung wisatawan 7 juta pertahun. Pengembangan Bandara Internasional Lombok ini juga mendukung upaya pembangunan KEK Mandalika dan mendukung penyelenggaraan acara MotoGP tahun 2021.

Selain dibukanya rute internasional dan pengembangan Bandara Internasional Lombok Praya, BUMN PT. Garuda Indonesia juga ikut serta dalam mendukung dijadikannya Kawasan Wisata Mandalika sebagai kawasan wisata bertaraf internasional dengan menambah frekuensi penerbangan domestik, membuka rute penerbangan domestik serta internasional. Adapun maskapai Garuda Indonesia memiliki rute domestik menuju Bandara Internasional Lombok, Praya langsung dari Jakarta, Denpasar dan Surabaya. Untuk kedepannya, PT. Garuda Indonesia akan membuka rute penerbangan langsung dari Yogyakarta menuju Lombok serta Makassar menuju Lombok. PT. Garuda Indonesia juga sedang mengupayakan untuk membuka rute penerbangan internasional baru yaitu penerbangan langsung dari Lombok menuju Guangzhou, Tiongkok. Pengembangan Bandara Internasional Lombok dan dibukanya rute penerbangan internasional langsung, serta penambahan beberapa penerbangan domestik secara langsung yang nantinya akan memudahkan wisatawan untuk berkunjung ke kawasan wisata Mandalika.

Disamping upaya maskapai plat merah yang mengupayakan penerbangan langsung ke Lombok semakin intens, beberapa maskapai lain juga memiliki rute penerbangan yang langsung menuju Lombok dalam upaya memudahkan wisatawan. Selain itu, maskapai asing yaitu Scoot maskapai milik Singapura telah memiliki rute penerbangan langsung dari Singapura menuju Lombok. Rute internasional lainnya dilakukan oleh maskapai Air Asia yaitu dari Kuala Lumpur, Malaysia menuju Lombok dan dari Perth, Australia menuju Lombok.

Disamping pengembangan Bandara Internasional Lombok, peningkatan aksesibilitas juga dilakukan dengan mengembangkan jalur lautnya. Melalui BUMN PT. Pelindo, upaya yang dilakukan meliputi pengembangan terminal pelabuhan Gili Mas di Teluk Lembar. Pengembangan pelabuhan ini meliputi pembangunan dermaga sepanjang 440 meter dengan kapasitas terminal penumpang mencapai 1.500 orang. Setiap tahunnya, jumlah wisatawan yang menggunakan kapal pesiar 
selalu meningkat. Tercatat pada tahun 2018, 139 unit kapal pesiar dan 126.119 wisatawan datang ke Lombok. Angka tersebut mengalami peningkatan sebesar 29,25 persen dari tahun sebelumnya (Pelindo III, 2019). Pengembangan melalui jalur laut ini dilakukan agar kapal pesiar dapat merapat dan efisien pada saat menurunkan wisatawan tanpa perlu lagi menurunkan jangkar di tengah laut. Selain itu, tujuan pengembangan pelabuhan untuk mempermudah konektivitas antar pelabuhan di Nusa Tenggara Barat. Rencana peningkatan aksesibilitas di kawasan Mandalika juga dilakukan dengan pengembangan Jalan Bandara Praya Mandalika serta Jalan Tol Bandara Praya-Mandalika.

Kawasan Wisata Mandalika yang telah menjadi kawasan wisata bertaraf internasional menjadi peluang bagi investor-investor asing untuk menanamkan modal di kawasan tersebut. Amenitas yang banyak diminati oleh sebagian besar investor baik dalam negeri maupun asing adalah pembangunan hotel dan villa di kawasan Mandalika.

Salah satu investor yang menanamkan modal di Lombok Mosaique Jiva One Sky yang merupakan gabungan perusahaan Jepang dan perusahaan Indonesia akan memanfaatkan lahan seluas 3,2 hektare untuk membangun hotel Royal Tulip di Kawasan Mandalika. Nantinya, Hotel Royal Tulip yang berada di kawasan Mandalika akan menyediakan 198 kamar yang terdiri dari 178 kamar dan 20 vila dengan nilai investasi sebesar Rp. 250 milyar. Selain itu, pembangunan hotel lainnya juga dilakukan untuk mendukung program peningkatan pariwisata khususnya di Mandalika. Amenitas yang berupa pembangunan hotel antara lain, pembangunan Hotel Pullman dengan nilai investasi mencapai Rp. 600 milyar, Hotel Paramount dengan nilai investasi mencapai Rp. 1 triliun, dan Hotel Club Med dengan nilai investasi mencapai Rp. 900 milyar.

Sektor amenitas lain yang sedang dikembangkan adalah pembangunan Islamic Center di Lombok dan Pembangunan Masjid Raya Mandalika yang disebut dengan Masjid Raya Nurul Bilad. Masjid Raya tersebut adalah masjid terbesar kedua setelah Islamic Center di Lombok. Masjid tersebut dibangun dengan desain megah yang mengambil nilai kearifan lokal dari Masjid Bayan, Lombok Utara. Terdapat juga adopsi dari bangunan adat di Sembalun, Lombok Timur. Pembangunan Masjid Raya tersebut juga merupakan program pemerintah khususnya Kementerian Pariwisata untuk menjadikan Nusa Tenggara Barat sebagai wisata halal atau Halal Tourism.

Pengembangan Amenitas lain yang dilakukan di kawasan wisata Mandalika adalah pengelolaan air untuk kebutuhan tersedianya air bersih. Pengelolaan tersebut dilakukan dengan melakukan perubahan atau mengolah air laut sehingga dapat dijadikan air layak untuk dikonsumsi di industri pariwisata. Pembangunan pengelolaan air tersebut dipantau 
langsung oleh PT. ITDC dan EBD Bauer, Perusahaan AS yang telah memiliki pengalaman dalam mengolah air laut. Dipilihnya perusahaan EBD Bauer karena perusahaan berpengelaman di beberapa negara seperti Arab Saudi, Bahrain, Filipina dan Turki dalam membangun fasilitas treatment plan air laut. Pengembangan pengelolaan air tersebut diberi nama Mandalika Eco Water. Mandalika Eco Water dimasa depan akan menyediakan ketersediaan air untuk hotel yang berada di KEK mandalika. Proses kerja dari Mandalika Eco Water ini menggunakan teknologi Sea Water Reverse Osmosis (SWRO) menghilangkan kadar garam air laut atau desalinasi air. Hasil dari pengelolaan air laut yang dapat diubah jadi air layak konsumsi dan segar yang siap dipakai dalam kebutuhan industri pariwisata tersebut direncanakan memiliki kemampuan untuk menghasilkan air layak pakai sebesar $3000 \mathrm{~m}^{3}$.

Dari segi atraksi, kawasan Mandalika memiliki potensi yang besar untuk dipromosikan potensi wisatanya. Mandalika merupakan kawasan teluk yang sangat indah, dengan pantai berpasir putih dan karangkarang yang nampak jelas di area perairan dangkalnya. Sementara di sisi lain, laut di Mandalika yang cukup dalam dapat digunakan untuk olahraga menyelam. Yang pertama merupakan mega proyek yang dengan mendatangkan investor asing, yaitu pembangunan sirkuit Moto GP oleh Vinci Construction Grand Projects (VCGP) yang berasal dari Perancis dan sudah menandatangani kontrak pembangunan sirkuit Moto GP pada November 2017. Pembangunan sirkuit tersebut akan dibangun sepanjang 4,8 kilometer. Perencaan Sirkuit MotoGP tersebut hanya dibangun di beberapa negara saja di Asia. Pihak investor MotoGP memilih Kawasan ini adalah ingin adanya kombinasi antara keindahan alam sekitar dengan olahraga. Pengunjung pun dapat dengan mudah melihat atraksi olahraga ini. Nilai investasi dari pembangunan sirkuit tersebut diperkirakan sebesar Rp. 6 triliun dan menjadikannya sebagai investasi terbesar di Mandalika. Sampai dengan bulan Juli 2020, pembangunan Sirkuit MotoGP telah mencapai tahap 50 persen dan rencananya pada bulan April 2021 sudah dapat memasuki tahap uji coba dan siap untuk menjadi tuan rumah perhelatan MotoGP 2021.

Selain megaproyek yang menjadi fokus daya tarik di kawasan ini, KEK Mandalika juga mempunyai pantai-pantai yang sudah dikena diantaranya yaitu Pantai Tanjung Aan, Pantai Kuta Lombok dan Pantai Seger. Pantai Kuta dengan keunikan pasir putihnya dan juga kejernihan air lautnya, ditambah dengan pemandangan bukitnya. Di samping Pantai Kuta Lombok, Pantai Tanjung Aan juga memiliki daya tarik yang tidak kalah indah. Namun kurang dikenal oleh wisatawan domestik tetapi memiliki daya tarik bagi wisatawan asing. Aktivitas pantai yang dapat dilakukan antara lain berjemur, berselancar dan olahraga menyelam. 
Di samping memiliki keindahan wisata maritim, kawasan wisata Mandalika juga memiliki potensi lain yang berupa desa wisata yaitu Desa Adat Sade dan Desa Adat Ende. Desa Adat Sade berada di dataran tinggi dengan luas sekitar lima hektar lebih yang terdiri sekitar 170 rumah adat asli masyarakat suku Sasak Loteng. Masyarakat Desa Adat Sade yang mana terkenal sebagai kelompok masyarakat yang kental dan ketat sekali dalam menjaga keaslian budaya yang diwariskan oleh leluhur mereka. Rumah adat di Kawasan ini semuanya dibangun dengan model yang hampir sama. Di samping Desa Adat Sade, terdapat juga Desa Adat Ende yang memiliki daya tarik wisata. Desa Adat Ende terletak di Desa Sengkol, Kecamatan Pujut, Lombok Tengah. Hal menarik dari Desa Adat tersebut ini adalah areanya yang lebih luas dibanding Desa Sade. Ketika menginjaki kaki di Kawasan desa ini, akan merasakan kesejukan dan ketenangan karena banyak sekali pohon-pohon di sepanjang jalan serta kotoran sapi dan kerbau akan tercium, namun hal ini bukan karena tidak disengaja. Kotoran sapi dan kerbau ini dapat berfungsi agar tanah liat yang menjadi alas rumah di desa Sade tetap bersih tidak banyak debu.

Atraksi terkenal yang menjadi daya tarik wisata di Mandalika antara lain Duel Tradisional Lombok, Peresean dan Festival Bau Nyale. Parasean merupakan salah satu bentuk promosi KEK Mandalika. Festival duel ini dimulai dengan berdoa terlebih dahulu sambil melingkar, lalu salah satu anggota membawa senjata tongkat dari rotan sembari membacakan mantra. Lalu kedua petarung terjun ke gelanggang dengan menggunakan senjata penjalin dan perisai. Disetiap bagiannya terdapat tiga ronde dimana setiap ronde berlangsung satu menit. Festival ini diiringi oleh gamelan khas Lombok. Walau banyak luka yang didapat oleh petarung namun tak membuat semangat mereka surut.

Sedangkan Festival Bau Nyale merupakan acara unggulan Provinsi Nusa Tenggara Barat. Festival Bau Nyale terdiri dari beberapa rangkaian acara, antara lain bersih pantai, parade budaya, surfing, voli pantai, lomba swafoto dengan kamera handphone, kampung kuliner, pemilihan Putri Mandalika, pagelaran, dan beragam acara hiburan. Bau Nyale ini merupakan suatu kebiasaan masyarakat setempat, khususnya penganut Wetu Tilu untuk mencari cacing (nyale). Tradisi ini erat kaitannya dengan Putri Mandalika yang diceritakan banyak pangeran yang berebut untuk menjadikannya seorang istri. Untuk dapat menjadi suaminya, putri Mandalika mendapati dirinya kebingungan untuk memilih siapa, yang pada akhirnya ia menjatuhkan dirinya ke laut. Cacing (nyale) ini sangat unik, mereka muncul hanya setahun sekali. Hal ini diyakini masyarakat setempat sebagai wujud dari Putri Mandalika. Tradisi ini dilakukan untuk melestarikan adat leluhur dan sebagai bentuk kerinduan terhadap Putri Mandalika. Tradisi ini sangat berlangsung meriah dan menarik, selain itu masyarakat juga melakukan pemotongan ayam dan membuat ketupat. 
Aksesibilitas, amenitas dan atraksi memang memegang peranan penting dalam sebuah wisata agar dapat menarik wisatawan baik domestik maupun mancanegara. Begitu juga di Kawasan Wisata Mandalika, dimana kriteria 3A menjadi faktor utama agar dapat menjadikan Mandalika sebagai kawasan wisata bertaraf internasional. Diharapkan dengan terpenuhinya kriteria tersebut, turis yang berkunjung ke kawasan wisata Mandalika dapat mengalami peningkatan serta sektor pariwisata akan mengalami peningkatan dalam menyumbangkan devisa negara.

Selain upaya mengembang kawasan wisata, pemerintah Indonesia juga melakukan upaya promosi ke luar negeri. Upaya ini sebagai bentuk diplomasi publik dalam koridor kebijakan luar negeri Indonesia. Outputnya adalah memberikan informasi maupun memberikan citra positif bagi masyarakat dunia terkait pariwisata Indonesia. Beberapa partisipasi yang dilakukan Indonesia dalam mengenalkan pariwisata 10 Destinasi Prioritas yang salah satunya adalah Mandalika antara lain, promosi Kementerian Pariwisata pada event Travel Tour Expo (TTE) pada 10-12 Februari 2017 di Manila, Filipina dengan agenda utama mengenalkan dan mempromosikan 10 'Bali Baru' sebagai potensi pariwisata Indonesia yang memiliki fasilitas bertaraf internasional (Kompas, 2017). Kementerian Pariwisata juga berpartisipasi dalam acara ASEAN C-Suite Investor Conference 2017 di Singapura. Partisipasi ini merupakan agenda pemerintah dalam memperkenalkan 10 destinasi prioritas Indonesia kepada masyarakat dan investor di Singapura (CNN Indonesia, 2017).

Promosi lainnya dilakukan oleh pemerintah melalui kantor perwakilan Kedutaan Republik Indonesia di Zagreb, Kroasia dengan mengusung tema "10 New Balis". Agenda ini sebagai upaya promosi potensi wisata Indonesia di pasar Eropa (Tempo, 2017). Promosi di kawasan Eropa juga dilakukan oleh KBRI Brussel, Belgia dengan berpartisipasi pada acara Brussels Holiday Fair yang diadakan oleh Brussels Expo pada 7 sampai 10 Februari 2019 (Indonews, 2019). Pameran khusus Mandalika juga diadakan oleh Kementerian Pariwisata dengan agenda menjadikan Mandalika sebagai destinasi wisata super prioritas. Acara ini bernama Pameran Pariwisata Mandalika: The Mandalika Tourismart yang diadakan pada tanggal 23 hingga 24 Agustus 2019 di Kawasan Ekonomi Khusus Mandalika.

Upaya pemerintah dalam mengembangkan wisata di Mandalika, Lombok tersebut merupakan salah satu bentuk dukungan dalam memajukan wisata Indonesia. Brand 'Wonderful Indonesia' dalam hal ini akan menjadi lebih dikenal oleh dunia. Diharapkan dengan upaya-upaya pemerintah dalam mengembangkan kawasan wisata Mandalika, kawasan tersebut dapat menjadi kawasan wisata bertaraf internasional dan menjadi kawasan wisata prioritas oleh wisatawan mancanegara. 


\section{Kesimpulan}

Pemerintah memiliki komitmen untuk menjadikan Indonesia sebagai poros maritim dunia. Apabila diturunkan dalam sektor pariwisata, pariwisata maritim menjadi satu dari prioritas-prioritas dalam pembangunan pariwisata nasional. Dengan adanya 'Wonderful Indonesia' pemerintahan negara Indonesia telah berusaha untuk mendorong peningkatan di sektor pariwisata, termasuk potensi dibidang maritim. Salah satu alasan Pemerintah mengupayakan promosi pariwisata dibidang maritim karena potensi sektor kelautan Indonesia yang sangat besar untuk dijadikan kawasan wisata yang bertaraf internasional, misalnya Kawasan Wisata Mandalika. Kawasan wisata Mandalika, yang menjadi salah satu dari ikon 10 Destinasi Prioritas Pemerintah juga memiliki peluang besar untuk dipromosikan bersama dengan brand 'Wonderful Indonesia' kepada dunia. Dalam pengembangan potensi pariwisata maritim, terdapat peluang untuk mendongkrak pertumbuhan ekonomi yang semakin baik, karena sampai saat ini pariwisata telah menjadi salah satu pemasukan devisa yang sangat baik bagi beberapa negara termasuk Indonesia. Peluncuran brand 'Wonderful Indonesia' telah memberikan dampak positif bagi Indonesia, misalnya pembangunan infrastruktur, peningkatan pertumbuhan ekonomi dan peningkatkan jumlah wisatawan yang berkunjung ke kawasan wisata tersebut.

Upaya dilakukan pemerintah dalam mendukung peningkatan wisata di Mandalika adalah dengan menjadikan kawasan ekonomi khusus dan menjadi salah satu proyek strategis nasional. Di samping itu, pemerintah juga melakukan upaya peningkatan di sektor 3A, yaitu akseibilitas yang berkaitan dengan cara wisatawan nantinya akan masuk ke kawasan wisata tersebut, amenitas yang berkaitan dengan tersedianya akomodasi di kawasan wisata tersebut serta atraksi yang berkaitan dengan apa yang dapat ditawarkan kepada wisatawan dari kawasan wisata tersebut. Pengelolaan kawasan ini dilakukan oleh PT Indonesian Tourism Development Corporation, yang merupakan salah satu BUMN yang bergerak di sektor pariwisata serta menggandeng beberapa investor asing yang mendukung berbagai sektor seperti hotel, pengelolaan air bahkan mega proyek berupa sirkuit MotoGP. Di samping itu, Pemerintah juga melakukan promosi 10 Destinasi Prioritas ini ke berbagai negara sebagai bentuk diplomasi publiknya.

Sebagai salah satu destinasi pariwisata, tentunya kawasan Mandalika dapat membawa dampak yang positif kepada berbagai pihak. Bagi pemerintah, adanya kawasan Mandalika dapat dijadikan mesin devisa dan menambah pemasukan baik bagi pemerintah pusat maupun daerah dari sektor kepariwisataan. Dan adanya kawasan wisata Mandalika juga menjadikan provinsi Nusa Tenggara Barat menjadi semakin maju, tentunya dengan melibatkan masyarakat setempat dalam mengembangkan 
kawasan wisata ini. Dengan upaya-upaya tersebut, kawasan Mandalika dapat menjadi kawasan wisata maritime yang bertaraf internasional serta memiliki potensi besar dalam meningkatkan target pemerintah dalam mendatangkan 20 juta wisatawan.

\section{Daftar Pustaka}

Amine, L. \& Chao, M. C. (2005). Managing Country Image to Long-Term Advantage: The Case of Taiwan and Acer. Place Branding, 1, pp. 187204.

Anholt, S. (2007). Competitive Identity: The New Brand Management for Nations, Cities and Regions. New York: Palgrave Macmillan.

Badan Pusat Statistik Nusa Tenggara Barat (2019). NTB, Maret 2019: Gini Ratio sebesar 0.379 Persen, s.l.: Badan Pusat Statistik.

Badan Pusat Statistik (2020). Perkembangan Pariwisata dan Transportasi Nasional Desember 2019 [Online]. Available at: https://www.bps. go.id/pressrelease/2020/02/03/1711/jumlah-kunjungan-wisman-keindonesia-desember-2019-mencapai-1-38-juta-kunjungan-.html. [Accessed 20 September 2020].

Bappeda NTB (n.d). Peluang dan Tantangan Kawasan Ekonomi Khusus Mandalika Tahun 2020 [Online] Available at: https://bappeda.ntbprov.go.id/peluang-dan-tantangankawasan-ekonomi-khusus-mandalika-tahun-2020/ [Accessed 18 September 2020].

CNN Indonesia (2017). Kemenpar Genjot Promosi 10 Bali Baru di Event Ini [Online] Available at: https:/www.cnnindonesia.com/gayahidup/20170526141315-307-217433/kemenpar-genjot-promosi-10-balibaru-di-event-ini [Accessed 20 September 2020].

CNN Indonesia (2017). Resmi Beroperasi, KEK Mandalika Serap Investasi Rp13 Triliun. [Online] Available at: https://www.cnnindonesia.com/ekono mi/20171020150615-92-249773/resmi-beroperasi-kek-mandalikaserap-investasi-rp13-triliun [Accessed 18 September 2020].

Cull, N. J. (2009). Public Diplomacy: Lessons from the Past. California: Figueroa Press.

Detik (2019). Investasi Infrastruktur MotoGP $\begin{array}{lllll}\text { Mandalika Telan } & \mathrm{Rp} & 14 & \text { Triliun. }\end{array}$ Available at: https://finance.detik.com/infrastruktur/d-4462753/ investasi-infrastruktur-motogp-mandalika-telan-rp-14-triliun [Accessed 18 September 2020].

Fan, Y. (2010). Branding the Nation: Towards a Better Understanding. Place Branding and Public Diplomacy, 6, pp. 97-103. 
Fitzpackrick, K., Fullerton, J. \& Kendrick, A. (2013). Public Relations and Public Diplomacy: Conceptual and Practical Connections. Public Relations Journal, 7(4), pp. 1-21.

Hartono, S. \& Faozaeni, E. (2018). Mandalika Punya Kita, Mataram: Exotica Senggigi.

Indarsih, G. (2016). Diplomasi Indonesia Melalui Kampanye Wonderful Indonesia Dalam Meningkatkan Pariwisata Indonesia di Dunia Internasional Tahun 2011-2015. Jurnal Online Mahasiswa Universitas Riau, pp. 1-15.

Indonews (2019). Indonesia Promosikan 10 Bali Baru di Brussel Holiday Fair 2019. [Online] Available at: https://indonews.id/artikel/19207/ Indonesia-Promosikan-10-Bali-Baru-di-Brussel-Holiday-Fair-2019/ [Accessed 20 September 2020].

Inside Lombok (2019). BPS: Jumlah Pengangguran di NTB Bertambah 1.260 Orang. [Online] Available at: https://insidelombok.id/berita-utama/ bps-jumlah-pengangguran-di-ntb-bertambah-1-260-orang/ [Accessed 18 September 2020].

Kementerian Pariwisata dan Ekonomi Kreatif (2019). Official Wonderful Indonesia Logo. [Online] Available at: https://www.kemenparekraf. go.id/page/official-wonderful-indonesia-logo [Accessed 20 September 2020].

Kementerian Komunikadi dan Informatika (2016). 10 Destinasi Pariwisata Prioritas 2016. [Online] Available at: https://kominfo.go.id/index.php/content/detail/7513/10destinasi-pariwisata-prioritas-2016/0/infografis [Accessed 19 September 2020].

Kompas (2017). 10 Bali Baru Dipromosikan di Manila. [Online] Availableat:https://travel.kompas.com/read/2017/02/11/171000927/10bali-baru-dipromosikan-di-manila?page=all [Accessed 20 September 2020].

Nurlelawati (2019). Diplomasi Budaya Indonesia Melalui Nation Branding Wonderful Indonesia Dalam Meningkatkan Kunjungan Wisatawan Mancanegara Di Mandalika 2011-2017. eJournal Ilmu Hubungan Internasinal Universitas Mulawarman, 7, pp. 1-12.

Pelindo III (2019). Pelabuhan Gili Mas Siap Dukung Mandalika dan Pariwisata Lombok, s.l.: s.n.

Statista Research Development (2020). s.l.: Statista Research Development.

Subarkah, A. R. (2018). Diplomasi Pariwisata Halal Nusa Tenggara Barat. Intermestic: Journal of International Studies, 2(2), pp. 188-203.

Sugi, S. P. \& Putri, A. (2019). Pengaruh Brand “Wonderful Pengaruh Nation Branding "Pesona Indonesia" Terhadap Preferensi Tujuan Wisata Masyarakat Kota Bandung Indonesia" Dalam Pembangunan Industri Pariwisata Indonesia. Jurnal Akuntansi Maranatha, 11(1), pp. 61-67. 
Tempo (2017). Destinasi Wisata 10 Bali Baru Dipromosikan Hingga ke Kroasia. [Online] Available at: https://travel.tempo.co/read/857719/ destinasi-wisata-10-bali-baru-dipromosikan-hingga-ke-kroasia/ full\&view $=$ ok [Accessed 20 September 2020].

Wiratama, H. D. (2017). Diplomasi Pariwisata Sebagai Nation Branding Indonesia Di Tingkat Global. Sidoarjo, Fakultas Ilmu Sosial dan Ilmu Politik Universitas Muhammadiyah Sidoarjo.

Yuristiadhi, G. \& Sari, S. D. L. (2017). Strategi Branding Pariwisata Indonesia Untuk Pemasaran Mancanegara. ETTISAL Journal of Communication, 2(2), pp. 31-41. 